\title{
Limitations to Freedom of Religion or Belief in Indonesia: Norms and Practices
}

\author{
Zainal Abidin Bagir \\ Graduate School, Universitas Gadjah Mada \\ zainalbagir@ugm.ac.id
}

Asfinawati

Jentera Law School and Indonesian Legal Aid Foundation, Jakarta asfin@ylbhi.or.id

\author{
Suhadi \\ Graduate School, State Islamic University Sunan Kalijaga, Yogyakarta \\ suhadi.cholil@uin-suka.ac.id
}

\author{
Renata Arianingtyas \\ Graduate School for Diplomacy, Paramadina University and The Asia \\ Foundation, Jakarta \\ renata.arianingtyas@asiafoundation.org
}

\begin{abstract}
The landscape of freedom of religion or belief (FoRB) in Indonesia has been shaped by two elements: first, the progressive adoption of human rights in the new laws and amended constitution, as a result of the democratization which started in 1998; second, the old governance of religion which acknowledges limited religious pluralism and emphasizes harmony over freedom. A striking feature resulting from this combination is the addition of "religious values" as a ground of FoRB limitation in the new chapter on human rights in the amended Constitution, which otherwise draws its inspiration from the ICCPR and other international human rights covenants. Indonesian "public order" and "public morals" are understood to consist of, among other things, respect and protection of religious values. While the emphasis on religious values and public order produces most restrictions, when it comes to limitations to FoRB on grounds of public health, the government seems reluctant to impose necessary restrictions.
\end{abstract}




\section{Keywords}

Indonesia - freedom of religion or belief - limitation clauses - religious values definition of religion - Constitutional Court

\section{The State of FoRB and Its Contexts}

The current situation of FoRB in Indonesia cannot be discussed without taking into consideration the democratisation that started more than 20 years ago, when the authoritarian regime which had ruled Indonesia for 32 years was ousted in May 1998. But it is clear too that the wide-ranging reforms that followed were also shaped by the politics and law of religious governance which has roots in the days around the declaration of independence in August 1945, and, to some extent, even goes back to the colonial time. The legal and political landscape of today's Indonesia has thus been shaped by several contradictory elements, in which the old and the new are mixed, resulting in a complex form of governance of religion. The norms and practices of limitations to FoRB reflect not only interpretations of limitation norms in the ICC PR, but of governance as well.

Indonesia, an archipelago consisting of some 30,000 islands and 300 ethnicities, is a majority Muslim country but has since the beginning of its history been religiously diverse. Hinduism and Buddhism were among the first dominant world religions coming to Indonesia, followed by Islam and Christianity. Other than the world religions, many indigenous or local religions had been present before them, though their number now is quite small. The latest census (2010) shows that Islam is embraced by 87 per cent of the population, Protestantism ca. 7 per cent, Catholicism ca. 3 per cent, Hinduism 1.7 per cent, Buddhism 0.72 per cent, Confucianism 0.05 per cent, and "others" o.13 per cent. ${ }^{1}$

The census, however, does not tell the whole story. First of all, while indeed Islam is the religion of the majority of Indonesians, the distribution of Muslims quite varies in different parts of Indonesia. For example, the island of Java, where more than half of all Indonesians live, is a majority Muslim area; Aceh is overwhelmingly Muslim (98 per cent); Bali is a majority Hindu region (8o per cent, compared with only 1.69 per cent in the national average). In

1 Agus Indiyanto, Agama di Indonesia dalam angka: dinamika demografis berdasarkan sensus penduduk tahun 2000 dan 2010 (Yogyakarta: Center for Religious \& Cross-cultural Studies (CRCS), 2013). 
many parts of Eastern Indonesia, Muslims are a minority, and Christians have significantly larger proportion: Catholics in the small province of Nusa Tenggara Timur constitute 36 per cent of the population (compared with 2.91 per cent in the national average); and in North Sumatra, Protestants make up 27 per cent of the population.

Second, it is not quite clear who the "others" are, but they would partly represent followers of indigenous religions. As discussed later, indigenous religions are not regarded as "religion", rather more as belief or culture, and administered not by the Ministry of Religious Affairs, but the Ministry of Education and Culture. What makes things more complicated is that groups of indigenous religions may have multiple religious affiliations: they may be considered as belonging to an indigenous religion, but at the same time profess to be Muslims, Christians, or members of other religious groups, and thus registered as such. This is a complexity that cannot be captured by the census. As discussed later, ambiguous religious affiliation poses a particular problem in the enjoyment of the right to FoRB.

Since its establishment in 1945, the Indonesian Constitution has protected FoRB, which stated that ' $[\mathrm{t}]$ he State guarantees all persons the freedom of worship, each according to his/her own religion or belief.'2 At the same time, as stated in the previous paragraph of the same article, 'the state is based on the belief in the One and Only God'. This was the result of the compromise between those who aspired to make Indonesia more Islamic (that is, by keeping a clause providing that there is an "obligation for Muslims to observe sharia" following the first article) and those who opposed it. In the years of 1955 and 2000, when the Constitution was amended, some Islamic political parties raised the issue again, trying to bring the clause back to the Constitution, and in both occasions they did not succeed. Indonesia has thus not been a religious state of any type, yet it also does not fit the general characterisation of a secular state that completely separates religion and state. This ambiguity has resulted in unfinished debates on issues related to the separation of state and religion, especially Islam, until today.

The Indonesian legal landscape changed drastically with the start of the democratisation in 1998. Within a few months a new law on human rights was released by Parliament. Between the years 2000-2002 the Constitution was amended four times; while Article 29 remains unchanged, a long and impressive chapter titled "Human Rights", with ten new articles, was added, signifying a stronger commitment to FoRB. Article $28 \mathrm{E}(1)$ mentions that every person "shall be free to choose and to practice the religion of his/her choice" along

2 Constitution, Article 29(2). 
with other rights such as the rights to education, employment, and citizenship; this is followed by Article $28 \mathrm{E}(2)$ mentioning that every person "shall have the right to the freedom to believe his/her faith and to express his/her views and thoughts, in accordance with his/her conscience." Article 28I(1) specifies that the rights to freedom of thought and conscience, and freedom of religion are among "human rights that cannot be limited under any circumstances." Seven international human rights treaties (including ICCPR and ICESCR) were ratified after 1998. The norm was mainstreamed in many new laws and regulations created after that. The non-discrimination principle, for example, appears in laws as diverse as the ones on resolution of social conflicts and disaster management. ${ }^{3}$ Another significant achievement was the establishment of the Constitutional Court, which was to become the most important interpreter of FoRB and as such also among the most important interpreters of limitations. This paper does not specifically discuss the Court, but many illustrations given here clearly indicate that.

Nevertheless, despite the overall better grounding of FoRB (and human rights in general), there are other developments that work in a different direction, in addition to the already ambiguous state-religion relationship as discussed earlier. Some expressions of the amended Constitution had, for instance, become a source of undue limitations. Most notably "religious values" is mentioned $\mathrm{d}^{4}$ as part of grounds of limitation along with other limitation grounds acknowledged by ICCPR.

Not less significantly, some pre-1998 laws and regulations are still valid; they have defined Indonesia's politics of religion and influenced contemporary governance of religions. They include laws on blasphemy and marriage, and regulations such as the one on building houses of worship. Another significant context that needs to be mentioned is decentralisation, as part of democratisation, which has enabled local governments and parliaments (in 34 Provinces and 514 districts/cities) to create local regulations. A number of these regulations are more restrictive than the national laws, or even discriminatory against particular religious groups. This article will refer to these trends to help understand the norms and practices of limitations of FoRB in Indonesia today.

3 Additionally, a Head of Police Circular (No. 8/2009) sets standards for the implementation of human rights in police works.

4 Constitution, Article 28J. 
The legal and political landscape, as described above, has created a complex form of governance of religion, in which several contradictory elements, the old and new, are mixed. The norms and practices of limitation of FoRB in Indonesia refer not only to what is mentioned in the ICCPR but reflect this governance as well.

There are several more commonly applied restrictive grounds of limitation at play in today's Indonesia. The first two are the way religion is defined and "religious values"; they are not mentioned in ICCPR, but quite influential. The way religion is defined affects not only FoRB, but also carries implications for other civil, political, economic and cultural rights. "Religious values", as mentioned in the amended Constitution, ${ }^{5}$ may in some ways relate to an interpretation of public morals, but in a more specific and narrower understanding of it. These two grounds of limitations make up a kind of Indonesian particularism, as implicitly acknowledged in several decisions of the Constitutional Court. They are foundational, in the sense that they affect the interpretations of other grounds of limitations mentioned in the ICCPR. Public order, as a ground of limitations in the ICCPR, is often interpreted broadly, because "order" also seems to comprise religious values claimed to be held by Indonesian society. Similarly, the understanding of public health is sometimes also coloured and limited by arguments grounded in an understanding of particular religious values.

\subsection{Limitations Grounded in How Religion Is Defined}

While the 1945 Constitution protects religious freedom, the scope of protection very much depends on what religion is. Restrictions that resulted as the consequence of the definition of religion are never stated explicitly in any norm, so they are rarely discussed in the literature on limitations which focuses on grounds and conditions of limitations as they appear in the ICCPR. Yet the definition is decisive in generating limitations, thus significantly reducing or even eliminating the rights of certain religious groups that are outside the boundaries of the concept.

General Comment No. 22 (1993) on Article 18 of the ICCPR construes religion broadly:

Article 18 protects theistic, non-theistic and atheistic beliefs, as well as the right not to profess any religion or belief. The terms "belief" and

5 Ibid. 
"religion" are to be broadly construed. Article 18 is not limited in its application to traditional religions or to religions and beliefs with institutional characteristics or practices analogous to those of traditional religions. ${ }^{6}$

In Indonesia, nowhere in the Constitution nor any of the laws is there any explicit definition of religion. Rather than the above-mentioned broad scope of religion, the history of the politics of religion in Indonesia, which goes back to at least the year 1945, has carried much more weight on this issue. This despite the fact that such "governed religion", to use Elizabeth Shakman Hurd's term, ${ }^{7}$ is much narrower than the rich lived religion of Indonesia, which comprises world religions as well as so many kinds of what scholars call indigenous religions and multiple religious affiliations. ${ }^{8}$ The governed religion determines whether a certain religious group is eligible for recognition, protection or state funding; the recognition in turn also affects other rights such as access to health and education.

To understand the Indonesian governed religion, we may trace it to a number of sources. First, there is Pancasila (five foundational principles of the state), as mentioned in the Preamble of the Constitution; each of the five is stated with brevity, in just one sentence. The first principle is "Belief in One and Only One God" which at the outset carries a monotheistic overtone characteristic especially of Islam. ${ }^{9}$ For any religion, even including Hinduism and Buddhism, to be recognised as such, it has to be conceived as monotheistic. ${ }^{10}$

6 Human Rights Committee, CCPR General Comment No. 22: Article 18 (Freedom of Thought, Conscience or Religion), CCPR/C/21/Rev.1/Add.4, para. 2.

7 Elizabeth Shakman Hurd, Beyond Religious Freedom: The New Global Politics of Religion (Princeton and Oxford: Princeton University Press, 2015).

8 The term world religions is contrasted here with indigenous religions. While the former is usually trans-national, the latter refers to local sets of practices and beliefs, held by a community that is usually tied to a specific geography (land or sea). The importance of this distinction, which is not made by ICCPR, will be shown later.

9 As different English translations of the original wording ("Ketuhanan Yang Maha Esa") show, Ketuhanan may not refer to a (personal) God, but divinity, which is more inclusive. In one version of interpretation, even non-monotheistic and atheistic beliefs are the subject of state recognition. See Zainal Abidin Bagir, 'The Politics and Law of Religious Governance in Indonesia', in Robert W. Hefner (ed.), Routledge Handbook of Contemporary Indonesia (London and New York: Routledge, 2018). It is hardly surprising that there is a contention over how the phrase should be understood among Muslims, Christians, Hindus and Buddhists, the discussion of which is beyond the scope of this article. See Suhadi. "I Come from a Pancasila Family": A Discursive Study on Muslim-Christian Identity Transformation in Indonesian Post-Reformasi Era (Zürich: LIT Verlag, 2014).

10 Michel Picard, 'Introduction: "Agama", "adat", and Pancasila', in Michel Picard and Rene Madinier (eds.), Politics of Religion in Indonesia: Syncretism, Orthodoxy, and Religious 
Some lower level regulations and ministerial circulars in the 1950s up to 1970 s seem to assume that what is understood as religion is world religions, with a tradition of prophecy, sacred scripture, and rituals. ${ }^{11}$

Next, in the Elucidation of the blasphemy law (lit. Law on Prevention of Misuse and/or Defamation of Religion, No. 1/PNPS/1965), some religions are mentioned as 'the religions embraced by the majority of Indonesian people', which receive state protection and funding. They are Islam, Christianity (Protestantism, Catholicism), Hinduism, Buddhism, and Confucianism. Other (world) religions (the examples given are Judaism, Zoroastrianism, Shintoism and Taoism) are not outlawed by the state but receive no assistance from the government. The Elucidation mentions the so-called 'streams of (spiritual) beliefs' (aliran kebatinan, an older name for aliran kepercayaan), which are not to be regarded as "religion". Together with what scholars of religion call indigenous or local religions, the latter category is ambivalently treated as culture, not religion. ${ }^{12}$

The immediate consequence of this way of defining religion affects the civil administration and, in turn, fulfilment of the citizens' basic rights. This can be illustrated by referring to the issues around the national identity card. Having the card is a way to access many basic rights such as health service, employment, education, and registration of marriage and birth. The problem is that the ID card has a religion column; one with an unclear religious affiliation may thus have difficulties in getting an ID card; even if he/she has one, he/she may experience tacit or explicit different treatment, if not outright discrimination. In the past (starting in the 1970s), one had to choose among six religions (Islam, Protestantism, Catholicism, Hinduism, Buddhism or Confucianism). Since 2006, a new civil administration law (No. 23/2006) allowed those who do not belong to one of the six religions to leave the column blank. While in a sense this is like an "exit option", those who choose this option (such as those belonging to an aliran kepercayaan, lit. streams of beliefs, or indigenous religions)

Contention in Java and Bali (London and New York: Taylor \& Francis, 2011), p. 3; Iem Brown, 'Contemporary Indonesian Buddhism and Monotheism', 18:1 Journal of Southeast Asian Studies (1987), pp. 108-117.

11 Niels Mulder, Mysticism \& Everyday Life in Contemporary Java: Cultural Persistence and Change (Singapore: Singapore University Press, 1978); Jane Atkinson, 'Religions in Dialogue: The Construction of an Indonesian Minority Religion', 10:4 American Ethnologist (1983), pp. 684-696; Robert Hefner, 'Religion: Evolving Pluralism', in Donald K. Emmerson (ed.), Indonesia Beyond Suharto: Polity, Economy, Society, Transition (New York: M.E. Sharpe), p. 206.

12 Samsul Maarif, Pasang Surut Rekognisi Agama Leluhur dalam Politik Agama di Indonesia (Yogyakarta: Program Studi Agama dan Lintas Budaya Universitas Gadjah Mada, 2017). 
still encounter difficulties to access government's services and receive social stigma. $^{13}$

In 2016 the law was challenged in the Constitutional Court by representatives of groups experiencing that kind of discrimination together with a few civil society organisations. ${ }^{14}$ The law stipulates that the identity card must have a religion column, but it may be left blank in the cases of adherent of two categories of "religion": citizens whose "religion is not yet recognized as religion according to existing regulations" and followers of aliran kepercayaan. While that was a significant improvement over the older law, in that it does not force one to choose only one out of the six, it was still seen as discriminatory. The petition asked the Court to enable them to fill in the name of their own religions/ beliefs in the religion column. In November 2017, the Court handed the decision which accepts the petition. The decision is quite significant, judging from the previous decisions of the Court, which in general are not as progressive as wished by human rights activists. The Court's acceptance implicitly means it regards them as "religion". Yet, opposition to the decision, which is most strongly voiced by the Indonesian Council of Ulama in the name of the old politics of religion, referred to as "national consensus", has apparently made the government reticent. The operative regulation which was then issued a few months later interpreted the Court's decision in an idiosyncratic way, which still assumes the distinction between (world) religion and beliefs/indigenous religions. Nevertheless, this recognition has made a significant impact at the grassroots level, with more members of the indigenous religions being given ID cards without having to leave the religion column blank or fill it in with one of the religions they are not affiliated with. Getting marriage and birth certificates too is now in general made easier.

\subsection{Limitations Grounded on Public Morals and "Religious Values"}

The Siracusa Principles do not specifically define public morals but acknowledge the relativity of public morality (i.e. that it 'varies over time and from one culture to another'). It seems clear that the Indonesian Constitution and laws draw inspiration from the ICCPR when mentioning moral or morality, yet the meaning given to it does not necessarily refer to the international discourse. In popular perception in Indonesia, moral or morality is closely associated

\footnotetext{
13 Ibid.

14 Marguerite Afra Sapiie, 'Constitutional Court rules indigenous faiths "acknowledged" by state', The Jakarta Post, 7 November 2017 <http://www.thejakartapost.com/news/ 2017/11/o7/constitutional-court-rules-indigenous-faiths-acknowledged-by-state.html\#>, 1 October 2018.
} 
with religion or religious values. Article 28J of the Indonesian Constitution mentions the limits of human rights in general, which includes morality and "religious values":

In exercising his/her rights and freedoms, every person shall observe the limitations as are prescribed by law for the sole purposes of guaranteeing the recognition and respect of the rights and freedoms of others and of satisfying just demands based upon considerations of morality, religious values, security and public order in a democratic society.

While the Constitution is the highest source of law, the first official support for human rights was the Parliament Decree (XVII/MPR/1998), which was issued only six months after the fall of the previous authoritarian regime in May 1998. Included in the decree are two texts titled 'The View and Attitude of the Nation of Indonesia on Human Rights' and 'Human Rights Charter', which mentions 'moral consideration, security and public order in a democratic society' (Article 36) as grounds of limitation of individual rights and freedom. In the 1999 Law on Human Rights, the chapter on limitations and prohibitions mentions moral decency (Ind. kesusilaan), public order and national interest (Article 73), but Article 23 of the same law adds "religious values" as another ground of limitation.

In all those documents, there are no precise definitions of both "morality" and "religious values". In practice, "religious values" is invoked often in Indonesia, as there seems to be a tacit assumption that morality is understood to refer mostly to religious values. Consequently, "religious values" has been used as a ground to limit FoRB significantly. This was evident, for example, in the 2010 Decision of the Constitutional Court to maintain the blasphemy law. ${ }^{15}$ Here the Court categorically accepts that the limitation clause in the Indonesian Constitution is different from Article 18 of the ICCPR. ${ }^{16}$ "Religious values" is understood in this context not only as moral, but apparently also as orthodoxy (i.e. correct theology). Thus, religious beliefs deemed "deviant" or incorrect may be prohibited and prosecuted without violating the constitutional guarantees of FoRB. ${ }^{17}$

15 Constitutional Court Decision No. 140/PUU-VII/2009, pp. 274-275.

16 Ibid., p. 276.

17 The importance of "religious values" in the amended Constitution cannot be exaggerated as it was one of the strong points of contentions between some Islamic political parties and others. For further discussion, see Bagir, supra note 10, pp. 285-295. 
In a few other decisions, the Court also indicates that "religious values" would include references to particular religious teachings which, at the same time, are deemed to be universal-i.e. affirmed by religions embraced by Indonesians. This is evident especially in the 2017 decision on the review of several articles related to adultery in the Penal Code. ${ }^{18}$ The Court did reject the petition which tried to broaden the articles in such a way that it would punish men and women conducting adultery and specifically outlaw homosexual relations. However, out of nine judges, four dissented. In their 12-page dissenting opinion, the dissenting judges made many references to the Qur'an while at the same time asserting that, all religions (in Indonesia) are against adultery. Further, due to the first principle of Pancasila, "Belief in One and Only God", Indonesian Constitution is a 'Godly Constitution and ... Indonesian laws should not reduce, narrow down, go beyond or even contradict "religious values and divine light".'19

This indicates how unclear are the boundaries of interpretation of "religious values". Indeed, when it comes to morals, there will always be debate. But the Siracusa Principles, it is reiterated, carefully mention that 'public morality varies over time and from one culture to another.' ${ }^{20}$ As such public moral should here be understood as derived from many traditions, religious or not, as well as philosophical and cultural traditions. In other words, it has to be inclusive, and cannot be discriminatory. ${ }^{21}$

Despite the significance of "religious values", it is also important to note that the implementation of limitations to FoRB in Indonesia do not always go in the direction of more accommodation of religious values. In some cases, demands to accommodate religious values are resisted. Examples of this sort appear in several Constitutional Court's reviews, such as the already mentioned Court's rejection to broaden the articles on adultery in the Penal Code and criminalize homosexual acts (2017), rejection to accommodate religious values (sharia or Islamic law) beyond personal and family laws to also include criminal laws (2011), and to remove restrictions against polygamy as part of Muslims' religious freedom (2007).

\footnotetext{
18 Constitutional Court Decision No. 46/PUU-XIV/2016.

19 Constitutional Court Decision No. 46/PUU-XIV/2016, 456-457.

20 Commission on Human Rights, Siracusa Principles on the Limitation and Derogation Provisions in the International Covenant on Civil and Political Rights (E/CN.4/1985/4, Annex), para. 27.

21 Muhamad Isnur, 'Pembatasan Hak Kebebasan Beragama atau Berkeyakinan' in Alamsyah M. Dja'far \& Atika Nur'aini (eds.), Buku Sumber Kebebasan Beragama atau Berkeyakinan (Jakarta: Wahid Foundation, 2016), pp. 400-401.
} 


\subsection{Limitations Grounded on Public Order, Safety and Security}

The Siracusa Principles define public order (ordre public) in the Covenant as 'the sum of rules which ensure the functioning of society or the set of fundamental principles on which society is founded. ${ }^{22}$ The dominance of religion in Indonesia, as discussed in the previous section, means that the notion of public order is also coloured by respect for religion. While in the Siracusa Principles '[r] espect for human rights is part of public order (ordre public),, ${ }^{23}$ in Indonesia, respect for religion/religious values or groups seems to have become part of public order.

The complexity of public order is not always related to religion. In the Indonesian language, the term has invariably been translated literally, as ketertiban umum/masyarakat, or as societal order. In the Penal Code, which was inherited from the Dutch, there is one chapter titled 'Crimes against Public/ Societal Order' (the original Dutch is openbare orde). The question hence is whether the public order in the Dutch Penal Code, as adopted by post-colonial Indonesia, and as it appears much more recently in ICCPR are the same. In the Penal Code, crimes against public/societal order comprise very many things, including expressions of hostility, hate or insult against the Indonesian government, Indonesian flags and state symbols, against religions in Indonesia or groups defined by reference to their ethnicity or religion; violating one's property, acts of violence against others, disturbing public meetings or public performance of religious rituals; all kinds of acts which create dangers for others; crimes against morality (kesusilaan), such as performing immoral acts or violation of morality, rape, indecency, women trafficking, abortion, hurting animals, etc. In this way "public order" comprises what is mentioned in ICCPR as public order, public health, public safety, public morals as well as rights of others. ${ }^{24}$

On the other hand, there is a tendency to understand public order rather narrowly as the antonym of disorder or chaos, which may invite armed response by the police or military. This is also related to a conflation of public safety and security. Curiously, in the translation of the ICCPR (which was made into Law No. 12/2005 on ratification of the ICCPR), the word "safety" in Article 18(3) was translated as keamanan, which actually means security (while safety should be translated as keselamatan). National security appears as a ground of restriction of freedom of expression (Article 19(3) ICCPR) but

\footnotetext{
22 Siracusa Principles, supra note 21, para. 22.

23 Ibid.

24 Cf. Yosep Adi Prasetyo et.al., Kajian Komnas HAM terhadap Peraturan Daerah DKIJakarta No. 8 Tahun 2007 tentang Ketertiban Umum (Jakarta: Komnas HAM, 2009), pp. 33, 44.
} 
not of FoRB (Article 18). This is not simply an issue of translation but carries important implications. That is, it supports a security approach to things regarded as violating public order.

Furthermore, while the purpose of limitation in this regard is to protect public order, in reality, there are claims justified on the basis of avoiding (potential or actual) disorder or chaos, without clear relations between the limitation and public order. This can be seen in the rationale of blasphemy (defamation of religion) cases. For example, a criterion that seems to be used by the government to take up a case of "defamation of religion" is mass media coverage of them or protests against them. ${ }^{25}$ In this case, usually it is the protests themselves which disrupt public order, rather than the acts of those accused of religious deviation or defamation; the protests may be the result of what one author has called "the manufacture of religious offense". ${ }^{26}$ This explains the fact why usually it is a minority (minority within a particular religion or a minority religion) which is criminalised in such cases.

Other than cases of defamation of religion, this reasoning also appears in criminal cases related to proselytism and including examples within the context of the Law on Protection of Children and rejection of licenses to build houses of worship. Just like in the defamation of religion cases, usually it is a minority who is accused of disturbing public order. Proselytism is not, strictly speaking illegal, but remains a sensitive issue and is discouraged.

This points to two characteristics of limitations grounded on public order in Indonesia. First, application tends to be discriminatory, as the FoRB of minority groups is limited to protect order, imagined or claimed, by the majority. Second, this is justified by reference to particular laws (including old, discriminatory laws), rather than on a principled interpretation of limitations in human rights norms. This may be related to the fact that judges have not internalised human rights norms, so they refer only to particular laws. ${ }^{27}$ But, beyond practical issues related to the conduct of judges, the prevalent interpretation of public order as a ground of limitation to FoRB has also shaped the state's paradigm of governance of religion. Limitations then are quite particularistic. Another point that needs to be highlighted here is the fact that public

25 Thanks to the participants in the workshop on limitations (July 2018; see note 1) for noting this point.

26 Cherian George, Hate-Spin: The Manufacture of Religious Offense and Its Threats to Democracy (Massachusetts: MIT Press, 2016).

27 Al Khanif, 'Model-Model Pembatasan Manifestasi Agama untuk Perlindungan Ketertiban Masyarakat', unpublished paper presented at the Workshop on Limitations of FoRB, Universitas Gadjah Mada, July 2018. 
order has also become the ground of limitation of freedom of expression, especially when the expression in one way or another relates to religion.

\subsection{Limitations Grounded on Public Health}

In the Siracusa Principles, '[p]ublic health may be invoked as a ground for limiting certain rights in order to allow a state to take measures dealing with a serious threat to the health of the population or individual members of the population. ${ }^{28}$ In contrast to the grounds of limitations discussed above (esp. public order and public morals), when it comes to public health, the main issue concerns limitations which, according to women's rights activists, should have been enforced to protect public health but are not in place. ${ }^{29}$ That is, government policies on public health are resisted by certain groups based on their particular religious understanding.

The main challenge here comes from a perception, held by many, that health is a private affair, affecting only oneself. However, public health is concerned with nurturing the health of the public which may be affected by certain individuals (e.g. epidemics), as well as with the wellbeing of a particular group of people, especially the vulnerable ones, such as women, children, or people with different sexual orientations. Prevention of diseases is as important and may involve enforcement of certain attitudes and behaviour.

Public health refers to the health of residents in an area or a community; it is not simply about diseases, but also individual behaviour as well as communal habits/customs which may contribute positively or negatively to the health of the people. It is as much concerned with addressing diseases, especially epidemic, as it is about providing a healthy space and having the right perception, attitude and behaviour toward what contributes to the public health, which includes understanding risk factors and avoiding them.

The World Health Organization explains public health as an 'approach to health that is concerned with the health of the community as a whole.' ${ }^{30}$ It has three core functions:

28 Siracusa Principles, supra note 21, para. 25.

29 Thanks to Budi Wahyuni, a representative of National Commission on Violence Against Women, for noting this at the workshop on limitations in Yogyakarta (July 2018, see note 1 ).

30 World Health Organization, A Glossary of Terms for Community Health Care and Services for Older Persons, available at <http://www.who.int/kobe_centre/ageing/ahp_vol5_glossary .pdf>, 16 October 2018. 
assessment and monitoring of the health of communities and populations at risk to identify health problems and priorities; the formulation of public policies designed to solve identified local and national health problems and priorities; and ensuring that all populations have access to appropriate and cost-effective care, including health promotion and disease prevention services, and evaluation of the effectiveness of that care. ${ }^{31}$

In line with that understanding, but at the same time broadening it, Indonesian law on health (No. 36/2009) understands health not only in physical terms, but also social, mental as well as spiritual. Besides concern with individual health services, public health includes prevention and treatment of disease/sickness, increasing health, and recovery of health. As such public health should also include education of health, work safety, reproductive health, environmental health, and epidemiology.

An example of the issue that constitutes serious religious challenges to public health is the objection to vaccination on the ground that, for Muslims, vaccines are not halal. But without vaccination, there may be an epidemic, raising the question whether such a religious objection should be accepted in the name of FoRB. It is important to note that in this case, apparently the issue turned out to be not as much about the haram-ness of vaccines, but failure to follow the procedure to do halal certification. ${ }^{32}$ This is a reminder-not limited to the issue of public health - that rather than imposing a limitation on certain rights, the government should try to fulfil the objective of the limitation (in this case protection of public health) using alternative means.

Other issues include the prohibition of child marriage, female genital mutilation, and the use of contraceptives (for reasons of safe sex or prevention of pregnancy), areas where reasoning is also sometimes based on religion. Nevertheless, there have always been diverse religious interpretations on these matters and in Indonesia, in general, the moderate interpretations which contribute positively to public health are relatively strong.

After 1998 human rights in Indonesia has progressed quite impressively as the Constitution was amended, the Constitutional Court established, new laws on

\footnotetext{
$31 \quad$ Ibid.

32 'Fatwa atau Nyawa', 31:47 Tempo (22-28 September 2018), available at <https://majalah .tempo.co/edisi/2399/2018-og-22>, 16 October 2018.
} 
human rights issued, and many international human rights treaties ratifiedall without reservations based on religion. However, the old paradigm of governance of religion, made up of laws on, and politics of, religion which came into being in the early days of Indonesian independence, has not changed. The coexistence of these two tendencies created obstacles for a fuller realisation of FoRB. "Prescribed by law" as the condition of limitations acknowledged in the ICCPR has not been effective to curtail undue limitations since many of the old (pre-1998), as well as new laws, are not harmonised with human rights in general, especially the ICCPR.

Limitations of FoRB in Indonesia mostly reflect a kind of "Indonesian particularism". This particularism is made up mainly of two elements: a politics of religion which has deep roots in history (at least since 1945, when Indonesia gained its independence, but to some extent further into the colonial times); and the dominance of religion in public life. In the discourse of FoRB, the two elements breed grounds of limitation of FoRB which are beyond what is acknowledged in ICCPR. Further, this particularism is reflected in the interpretation of legitimate grounds of limitations, as mentioned in the ICCPR, mainly public order and public morals, but also public health. While the government puts more emphasis on restrictions grounded on an interpretation of public order and public morals, it seems reluctant to impose restrictions on religionbased claims to protect public health where they are necessary.

Public order as a broad concept expressing (the perception of) Indonesian social order comprises public safety, public health and public morals. This idea is apparent in the chapter on 'Crimes against Public Order' of the Penal Code. The idea of Indonesian social order reflects both the state's and the majority's (Muslim) perceptions. The term "Muslim majority" needs clarification. First, in reality, there has always been a variety of Muslim interpretations on particular issues (such as religious defamation or blasphemy, the LG BT community, child marriage, and polygamy). Second, in some cases, what is claimed as "Islamic values" on the above issues are also claimed to be universal teachings of all religions, such as in the argument of judges of the Constitutional Court when reviewing the law on adultery and same-sex relations (2017).

In general, debates on those issues appear most vividly in the Constitutional Court whose task is to review laws against the Constitution and has been the most important interpreter of human rights. What happens at the Court may tell us the prospects for FoRB in Indonesia. So far the Court has reviewed not less than 17 cases related to religion. Examining a number of the Court's decisions, Butt sees that the Court's approach to religion is ambiguous, or even inconsistent. He says that 'it will not provide more space within the Indonesian legal and political sphere for religion and Islamic law', yet maintains that 'the Indonesia state is not secular, but religious' since 'the Constitutional Court 
needed to consider religious values when reviewing the constitutional validity of statutes.' 33

Indeed, the Constitutional Court's position is not as progressive as wished by human rights activists. Yet it also does not follow the most conservative religious, especially Muslim, groups demanding broader and more comprehensive accommodation of what they argue as religious values (sometimes claimed as "universal") and their enforcement by the state. Therefore the Court has, in a sense, maintained what can be called the "middle path". This reflects what seems to be a common view by the state as well as some scholars. While considerations about legitimate limitations listed by the ICCPR is not completely absent, a more important determinant factor seems to be the idea of Indonesia as a non-religious, yet also non-secular country, in which religious diversity is acknowledged and at the same time (certain) religious values are allowed to be effective in public. In this regard, the 2017 decision on indigenous religions seems to constitute an important exception. The fact that the government's operative regulation, a follow up to the decision, is regarded as not fully reflecting the Constitutional Court's decision, may indicate that an important rupture in the decades-long politics of religion is hard to achieve, but not impossible.

Two of the most important obstacles in advancing FoRB in Indonesia are the lack of relatively precise interpretations of legitimate grounds of limitations in the ICCPR and the country's legacy of a particular paradigm of governance of religion. The combination of the two creates a situation in which restrictions of FoRB are justified within a kind of broad notion of Indonesian particularism. Even if a more precise and principled interpretation can be attempted, it may not change the situation of FoRB as long as the deep-rooted paradigm does not change. Attempts to change it, while not impossible, would undoubtedly take a long time.

In this situation, there are two strategies that may be carried out simultaneously to improve FoRB in Indonesia today. First, though difficult and far from ideal, advocacy for FoRB could and should undoubtedly still continue within the confines of the current laws and politics of religion and not in opposition to it. ${ }^{34}$ To address ambiguities, lack of clarity and even inconsistencies related to limitations of FoRB, a study of limitations in global discourse of universal

33 Simon Butt, 'Between Control and Appeasement: Religion in Five Constitutional Court Decisions,' in Tim Lindsey and Helen Pausacker (eds.), Religion, Law and Intolerance in Indonesia (London and New York: Routledge, 2016), pp. 6o-61.

34 See a recent discussion of Singapore: Jaclyn Neo, 'Secularism without Liberalism: Religious Freedom and Secularism in a Non-Liberal State', 2 Michigan State Law Review (2017), pp. 333-370, who discusses a secular but non-liberal approach to FoRB in Singapore. In both Indonesia and Singapore, "harmony" is more central than "freedom". 
human rights would help significantly. However, it is equally important to study how conceptions such as public order, safety, health and morals are discussed and implemented in the actual Indonesian context. More studies of past cases and decisions are imperative to find a more accurate pattern of limitations of FoRB in Indonesia. One of the promising ways to do this is by studying more carefully the Constitutional Court's reasoning about limitations as well as laws or regulations that contain limitation-style rationales. This is especially true in the contentious Indonesian notion of "religious values" as a ground of limitation. Normatively speaking, and in parallel with the discussion about public morals, "religious values" need to be at least understood in an inclusive way. Such an attempt to clarify the understanding of limitations may result in a set of guidelines of interpretation based on global human rights discourse as well as Indonesian experience. While the existing paradigm is still in play and discriminatory laws are still in place, advocacy for FoRB may take the form of providing such operational guidelines, to be used by the police, prosecutor, judges, and the Supreme Court, to make the implementation of the laws less discriminatory.

Second, while working from within the system, advocacy for FoRB in Indonesia may use any opportunity, when it presents itself, to attempt the more fundamental changes, even if gradually. Such an opportunity may come when the Government's plan to create a draft bill on protection of religious communities is followed up. Such a bill was attempted several times in the past fifteen years. In 2003 and 2011 draft bills on religious harmony were countered by human rights activists and did not make it to Parliament. ${ }^{35} \mathrm{~A}$ third draft was made in 2016 and is still being discussed by the Ministry of Religious Affairs, now with a more acceptable title no longer containing the word "harmony" (which was seen as not always in line with freedom), but "protection of religious communities".

Another example is the on-going discussion on the revision of the Penal Code. The present draft has made some improvements, yet still contains objectionable elements such as the prohibition of (vaguely defined) blasphemy. The 2017 Constitutional Court's decision on indigenous religions is another good example, though, as mentioned above, it has its own limitations. In sum, while there are avenues to advocate for a better situation of FoRB, challenges will remain.

35 Melissa Crouch, 'Shifting Conceptions of State Regulation of Religion: The Indonesian Draft Law on Inter-religious Harmony', 25:3 Global Change, Peace \& Security (2013), pp. 1-18. 


\section{Acknowledgements}

In writing this paper the authors benefitted from the presentations and discussion at the Workshop on Limitations of FoRB in Indonesia, 5-6 July 2018 held in Universitas Gadjah Mada, Yogyakarta; as such we thank the participants of the workshop. The workshop was the result of collaboration between the Center for Religious and Cross-cultural Studies, Graduate School, Universitas Gadjah Mada; Indonesian Legal Aid Foundation, Jakarta; National Commission on

Human Rights, Jakarta; Oslo Coalition on Freedom of Religion and Belief; and The Asia Foundation, Jakarta. 